\title{
Constraints Faced by Agriculture Farmers during Drought in Drought Prone Western Odisha
}

\author{
Devi Prasanna Swain ${ }^{1 *}$, Arunasis Goswami ${ }^{1}$, Bhabesh Chandra Das ${ }^{2}$, \\ Debasis Ganguli $^{1}$ and Bikash Santra ${ }^{1}$ \\ ${ }^{1}$ Department of Veterinary and Animal Husbandry Extension Education, \\ WBUAFS, Kolkata, India \\ ${ }^{2}$ Department of Veterinary and Animal Husbandry Extension Education, OUAT, Odisha, India \\ *Corresponding author
}

\section{A B S T R A C T}

\section{Keywords}

Drought, Odisha, Agriculture farmers, Constraints

\section{Article Info}

Accepted:

17 September 2020

Available Online:

10 October 2020
Agriculture is severely affected by the irregular climate variations like drought, flood etc. and thus the farmers also have to face a phase of crisis during the period. The study was undertaken to recognize the major constraints faced by agriculture farmers in drought prone western Odisha. A total of 194 respondents engaged in agriculture farming as their primary occupation selected randomly from 3 district of western Odisha namely Balangir, Kalahandi and Nuapada by stratified random sampling. With several interactions with experts from different area ten most possible and relevant constraints and the farmers were questioned. As per their responses drought threatened household food security, erratic rainfall caused drought and subsequent loss of crops, distress sale of capital resources due to drought were ranked $1^{\text {st }}, 2^{\text {nd }}$ and $3^{\text {rd }}$ constraints faced by the farmers whereas constraints like pest-attack and disease infestation in crops, reduction in household income, lack of irrigation facility brought in crop loss and low harvest, lack of inputs for alternate crops during and just after drought, inadequate storage facility to store the previous years' produce, drought affected schooling of children, affected the social and psychological wellbeing where other constraints and they ranked from $4^{\text {th }}$ to $10^{\text {th }}$ respectively. The study revealed that farmers are not able to meet their household food requirement and thus drought affects the agriculture farmers severely.

\section{Introduction}

A drought is a natural disaster of belowaverage precipitation in a given region; consequential in prolonged shortages in the water supply of atmospheric, surface water or ground water (Swain et al., 2019). However, agricultural drought refers to stressed and declined vegetation growth condition over a period of time due to shortage of precipitation, high surface temperature and deficit in soil moisture (Son et al., 2012). Impact of drought is related to social, economic, political factors as well as climatologically aspects (Campbell, 1984). Wilhite (2016) observed that drought is one of the costliest natural hazards in Europe. Farmers are regularly facing problems 
associated with unreliable rainfall and soils of low fertility, unlike animal husbandry farmers who can adjust grazing patterns to their modified access to pasture and water and also can take nomadic way of living (Campbell, 1984). The western Odisha is more dependent on the monsoon rainfall for farming, goes through the situations like drought frequently which can be once in two years (Swain, 2019). Farmers in this region are either marginal or share croppers mostly, which makes them more venerable to this climatic calamity. Prolonged droughts result in mass migrations and humanitarian crisis. It can have a substantial impact on the ecosystem and agriculture of the affected region and harm to the local economy.

Bihar, Uttar Pradesh, Karnataka, Kerala, Maharashtra encounters drought more often in than other states in India Swain (2019). In nine out of past 15 years, about 100 districts of the country have witnessed a drought likesituation, triggered by failure of south-west monsoon. Farm distress in Odisha worsened this when the kharif crop was severely impacted by scanty rainfall in July and August. According to the official records, crop area of 21.6 lakh ha is affected, out of which at least 14.82 lakh ha in 233 blocks in 27 districts have suffered losses over $33 \%$. The worst affected district is Mayurbhanj followed by Bargarh, Balangir, Keonjhar and Nayagarh districts. Districts of western Odisha lack proper irrigation facilities and thus irregular monsoon harms the crop leaving the farmer in a miserable condition where he is unable to maintain his family and repay his debts (Special Relief commissioner's office, 01 Nov 2018.) hence the study was made to know the major constraints faced by agriculture farmers during drought conditions and as well to rank them in the drought prone Balangir, Kalahandi and Nuapada districts of Odisha.

\section{Materials and Methods}

\section{Area under study and selection of respondents}

Western part of Odisha comprises of districts namely, Sambalpur, Bargarh, Kalahandi, Nuapada, Balangir, Sonepur, Deogarh, Jharsuguda and Sundargarh out of which, Balangir, Kalahandi and Nuapada face frequent droughts and simultaneously don't have any option to provide livelihood activities to the localites at the time of drought. Almost $70 \%$ residents in these districts earn their livelihood out of agriculture, animal husbandry and agriculture labour. So, these three districts are selected for the study purposively based on the findings as cited.

The data were collected from one block from each district namelyBangomunda block of Balangir, Golamunda block of Kalahandi and Boden block of Nuapada. These three blocks were proposed because, these blocks face severe drought and there is no other source of livelihood for the farmers. These blocks lack any major irrigation project or any industry to provide livelihood to the farmers during drought. Moreover, these blocks lie adjacent to each other in a patch which will make the data collection more relevant and easier. During the study, randomly 194 respondents were interacted whose primary occupation was agriculture in a stratified random sampling method.

\section{Preparation of the interview schedule}

A pilot study was conducted and a relevant questionnaire was finalised after being consulted, discussed, cross checked, verified with experts, stake holders after judging each item with possible linkage as per the objective set forth in the study. Repeated verifications and proper measures were taken to avoid 
vague and ambiguous responses that may distort the information flow. Close ended questions were put in the schedule to get appropriate response.

\section{Constraints of livelihood generation during drought in Agriculture}

Constrain refers to the unnatural behaviour that sometimes is the result of forcing yourself to act in a particular way. This otherwise can be defined as something that controls what you do by keeping you within particular limits.

Droughts are common phenomena in many parts of Western Odisha which results due to deficit in rain. Not only is the region droughtprone, but the rural communities inhabiting these areas are well aware of the adverse effects of droughts on their environmentdependent livelihoods. Small farmers, who are the most likely to experience disruptions to their production efforts, are even more vulnerable during droughts. There are several constraints face by the farmers during drought. The agriculture farmers were asked 10 particular statements and they had to score each statement in 1 to 5 score card. 10 statements related to constraints are randomly arranged in the questionnaire, and the respondents were asked to assign rank in order of most difficult one to least difficult one. The statement which was mentioned as highest constraint by the respondents is given rank 1 and the least is given 10, therefore, in total, 10 statements were asked to the farmers according to their primary occupation. Constraints were ranked on the basis of Garrett's ranking technique.

\section{Data Analysis}

The statistical measures employed in this study for interpretations of data were explained herewith Percentage, Rank Order and Garrett's ranking Technique. On the basis of the mean score, rank order was made. The item securing highest mean score was given first rank, next highest second rank and so on. It was assigned to items in roman numericals (I, II, III, IV ...). To find out the most significant constraint which influences the respondent, Garrett's ranking technique was used. As per this method, respondents have been asked to assign the rank for all constraints and the outcome of such ranking was converted into score value with the help of the following formula:

Percent position $=100(\mathrm{Rij}-0.5) / \mathrm{Nj}$

Where, $\mathrm{Rij}=$ Rank given for the ith variable by jth respondents

$\mathrm{Nj}=$ Number of variables ranked by $\mathrm{jth}$ respondents

With the help of Garrett's table, the percent position estimated is converted into scores. Then for each constraint, the scores of each individual are added and then total value of scores and mean values of score is calculated. The factors having highest mean value is considered to be the most important constraint and ranked 1st. the factors having lowest mean value is considered to be the least important constraint and ranked last (Table 1).

\section{Results and Discussion}

Drought causes severe damage to the agricultural crops and thus farmers go though a period of hardship where they are unable to earn their livelihood, which generates many constraints for the farmers to deal with. The most probable ten constrains were summed up in Table 2 and attempt was made to rank them depending on the responses of the farmers.

Among the agricultural farmers $78.87 \%$ respondents strongly agreed to the statement 
that Erratic rainfall caused drought and subsequent loss of crops, whereas $67.53 \%$ ranked lack of irrigation facility brought in crop loss and low harvest to be very severe. Majority of respondents $(91.76 \%)$ ranked Lack of inputs for alternate crops during and just after drought as a very severe or a severe constraint for agriculture farmers.

On enquiring regarding the extent of concern of Drought threatened household food security, $83.51 \%$ respondents answered as very severe followed by $16.49 \%$ to be severe which suggests that all, the respondents indicated that drought threatened household food security severely.

Majority of respondents suggested inadequate storage facility to store the previous years' produce is also a severe constrain resulted from drought. $79.38 \%$ responded ranked Drought caused Distress sale of capital resources as a very severe constraint, $14.43 \%$ ranked as severe, $4.12 \%$ ranked moderate, and combined together $2.06 \%$ respondents ranked either as of very low or low concern. All most all $(93.81 \%)$ respondents stated drought caused problem of pest-attack and disease infestation in crops as either a very severe $(69.07 \%)$ or a severe $(24.74 \%)$ constraint for them to generate their livelihood. $28.87 \%$, $45.36 \%, 8.76 \%, 13.40 \%$ and $3.61 \%$ respondents thought respectively to be very severe, severe, moderate, low and very low on being asked the extent of concern of drought affecting schooling of children.

On questioning the extent of concern of drought triggering reduction in household income, $68.56 \%$ respondents thought that the extent of concern was very high, where as $24.23 \%$ thought it to be severe. All most all respondents rated that drought affected the social and psychological well being is was rated low by agriculture respondents.

\section{Analysis of data on constraints of livelihood during drought in agriculture}

The rank order of constraints faced by Agricultural farmers during drought for their livelihood is presented in the Table 3. Among the constraints, difficult to meet the household food requirement was ranked as I by the respondents, whereas constraint related to erratic rainfall causing drought, crop loss, distress sell of capital resources, and problem of pest attack and disease infestation in crops due to droughts were ranked II, III, and IV, respectively as respondents. Reduction of house expenses and other expenses was ranked $\mathrm{V}$ by the respondents. Followed by lack of irrigation facility, lack of inputs for alternative crops, inadequate storage facility, affected schooling of children and affected the social and psychological well being as ranked as VI, VII, VII, IX and $\mathrm{X}$, Respectively.

Karmee (2017) reported that with drought stalking districts of Nuapada, Balangir, Kalahandi and rain-fed areas of Bargarh, the peasants and marginal farmers have been robbed of their purchasing power. Karmee (2017) reported that with drought stalking districts of Nuapada, Balangir, Kalahandi and rain-fed areas of Bargarh, the peasants and marginal farmers have been robbed of their purchasing power, which is also indicated in this study as the farmers were compelled towards a distress sell their capital resources, which is also observed in the present study as the respondents pointed out that the difficulty to meet the household food requirement most important constraint. Then according to the farmers, erratic rainfall caused drought and subsequent loss of crops that means maximum respondents identified the lack of required amount of water and suitable alternative to provide the deficit water are the major constraints faced by the farmers during drought. 
Table.1 Garrett's ranking technique of scoring followed in the study

\begin{tabular}{|l|l|l|}
\hline SI. NO & Variable & Response \\
\hline $\mathbf{1}$ & Very Sever & 5 \\
\hline $\mathbf{2}$ & Sever & 4 \\
\hline $\mathbf{3}$ & Medium & 3 \\
\hline $\mathbf{4}$ & Less & 2 \\
\hline $\mathbf{5}$ & Very Less & 1 \\
\hline
\end{tabular}

Table.2 Response of respondents as per their constraints of livelihood during drought in agriculture $(\mathrm{n}=194)$

\begin{tabular}{|c|c|c|c|c|c|c|}
\hline \multirow[t]{2}{*}{$\begin{array}{l}\text { SI. } \\
\text { No }\end{array}$} & \multirow[t]{2}{*}{ Constraints } & \multicolumn{5}{|c|}{$\begin{array}{c}\text { Response } \\
\text { No. (percent) }\end{array}$} \\
\hline & & $\begin{array}{l}\text { Very } \\
\text { Severe }\end{array}$ & Severe & Moderate & Low & $\begin{array}{l}\text { Very } \\
\text { Low }\end{array}$ \\
\hline 1 & $\begin{array}{l}\text { Erratic rainfall caused drought and } \\
\text { subsequent loss of crops }\end{array}$ & $\begin{array}{c}153 \\
(78.87)\end{array}$ & $\begin{array}{c}35 \\
(18.04)\end{array}$ & $\begin{array}{c}2 \\
(1.03)\end{array}$ & $\begin{array}{c}2 \\
(1.03\end{array}$ & $\begin{array}{c}2 \\
(1.03)\end{array}$ \\
\hline 2 & $\begin{array}{l}\text { Lack of irrigation facility brought in } \\
\text { crop loss and low harvest }\end{array}$ & $\begin{array}{c}131 \\
(67.53)\end{array}$ & $\begin{array}{c}46 \\
(23.71)\end{array}$ & $\begin{array}{c}9 \\
(4.64)\end{array}$ & $\begin{array}{c}6 \\
(3.09)\end{array}$ & $\begin{array}{c}2 \\
(1.03)\end{array}$ \\
\hline 3 & $\begin{array}{l}\text { Lack of inputs for alternate crops } \\
\text { during and just after drought }\end{array}$ & $\begin{array}{c}109 \\
(56.19)\end{array}$ & $\begin{array}{c}69 \\
(35.57)\end{array}$ & $\begin{array}{c}12 \\
(6.19)\end{array}$ & $\begin{array}{c}3 \\
(1.55)\end{array}$ & $\begin{array}{c}1 \\
(0.52)\end{array}$ \\
\hline 4 & $\begin{array}{l}\text { Drought threatened household food } \\
\text { security }\end{array}$ & $\begin{array}{c}162 \\
(83.51)\end{array}$ & $\begin{array}{c}32 \\
(16.49)\end{array}$ & $\begin{array}{c}0 \\
(0.00)\end{array}$ & $\begin{array}{c}0 \\
(0.00)\end{array}$ & $\begin{array}{c}0 \\
(0.00)\end{array}$ \\
\hline 5 & $\begin{array}{l}\text { Inadequate storage facility to store the } \\
\text { previous years' produce }\end{array}$ & $\begin{array}{c}55 \\
(28.35)\end{array}$ & $\begin{array}{c}109 \\
(56.19)\end{array}$ & $\begin{array}{c}14 \\
(7.22)\end{array}$ & $\begin{array}{c}8 \\
(4.12)\end{array}$ & $\begin{array}{c}8 \\
(4.12)\end{array}$ \\
\hline 6 & $\begin{array}{l}\text { Distress sale of capital resources due } \\
\text { to drought }\end{array}$ & $\begin{array}{c}154 \\
(79.38)\end{array}$ & $\begin{array}{c}28 \\
(14.43)\end{array}$ & $\begin{array}{c}8 \\
(4.12)\end{array}$ & $\begin{array}{c}2 \\
(1.03)\end{array}$ & $\begin{array}{c}2 \\
(1.03)\end{array}$ \\
\hline 7 & $\begin{array}{l}\text { Pest-attack and disease infestation in } \\
\text { crops }\end{array}$ & $\begin{array}{c}134 \\
(69.07)\end{array}$ & $\begin{array}{c}48 \\
(24.74)\end{array}$ & $\begin{array}{c}6 \\
(3.09)\end{array}$ & $\begin{array}{c}4 \\
(2.06)\end{array}$ & $\begin{array}{c}2 \\
(1.03)\end{array}$ \\
\hline 8 & $\begin{array}{l}\text { Drought affected schooling of } \\
\text { children }\end{array}$ & $\begin{array}{c}56 \\
(28.87)\end{array}$ & $\begin{array}{c}88 \\
(45.36)\end{array}$ & $\begin{array}{c}17 \\
(8.76)\end{array}$ & $\begin{array}{c}26 \\
(13.40)\end{array}$ & $\begin{array}{c}7 \\
(3.61)\end{array}$ \\
\hline 9 & Reduction in household income & $\begin{array}{c}133 \\
(68.56)\end{array}$ & $\begin{array}{c}47 \\
(24.23)\end{array}$ & $\begin{array}{c}8 \\
(4.12)\end{array}$ & $\begin{array}{c}4 \\
(2.06)\end{array}$ & $\begin{array}{c}2 \\
(1.03)\end{array}$ \\
\hline 10 & $\begin{array}{l}\text { Affected the social and psychological } \\
\text { well being }\end{array}$ & $\begin{array}{c}0 \\
(0.00)\end{array}$ & $\begin{array}{c}0 \\
(0.00)\end{array}$ & $\begin{array}{c}0 \\
(0.00)\end{array}$ & $\begin{array}{c}18 \\
(9.28)\end{array}$ & $\begin{array}{c}176 \\
(90.72)\end{array}$ \\
\hline
\end{tabular}

(The figures in upper row is frequency and lower is percentage in $3^{\text {rd }}, 4^{\text {th }}, 5^{\text {th }}, 6^{\text {th }}, 7^{\text {th }}$ columns) 
Table.3 Rank order of constraints faced by agricultural farmers for their livelihood during drought

\begin{tabular}{|c|l|c|c|}
\hline S. & \multicolumn{1}{|c|}{ Constraints } & \multicolumn{2}{|c|}{ Response } \\
\cline { 2 - 4 } No & & \multicolumn{1}{|c|}{ Mean Score } & Rank Order \\
\hline $\mathbf{1}$ & Erratic rainfall caused drought and subsequent loss of crops & 4.73 & II \\
\hline $\mathbf{2}$ & Lack of irrigation facility brought in crop loss and low harvest & 4.54 & VI \\
\hline $\mathbf{3}$ & Lack of inputs for alternate crops during and just after drought & 4.45 & VII \\
\hline $\mathbf{4}$ & Drought threatened household food security & 4.84 & I \\
\hline $\mathbf{5}$ & Inadequate storage facility to store the previous years' produce & 4.01 & VIII \\
\hline $\mathbf{6}$ & Distress sale of capital resources due to drought & 4.70 & III \\
\hline $\mathbf{7}$ & Pest-attack and disease infestation in crops & 4.59 & IV \\
\hline $\mathbf{8}$ & Drought affected schooling of children & 3.82 & IX \\
\hline $\mathbf{9}$ & Reduction in household income & 4.57 & V \\
\hline $\mathbf{1 0}$ & Affected the social and psychological well being & 1.09 & $\mathrm{X}$ \\
\hline & & & 41.34 \\
\hline
\end{tabular}

Rainfall variability, drought intensity and shortage of available water holding capacity of soil are the most influential biophysical factors of drought vulnerability whereas low irrigation development, poor crop insurance coverage and smaller forest area are the most influential socioeconomic factors (Swain and Swain, 2011). Swain and Swain (2011) also indicated that rainfall variability, soil type, land topography, groundwater availability and utilization, irrigation coverage, economic strength and institutional support system are some of the key factors that determine the nature and extent of drought vulnerability in a region. Drought results in reduction in yield of cereals, horticultural crops, livestock production and loss of employment; all associated with decreased income of farmers, and were the most immediate economic impacts of drought (Udmale et al., 2014), which was also reflected as majority of farmers were not able to support the schooling of their ward and also indicated towards the decline in their income. For an agricultural farmer, his financial stability is hugely affected by the drought condition. Due to loss in agriculture they don't get enough work to earn and sustain their livelihood. Due to loss in agriculture they don't get enough work to earn and sustain their livelihood. Social impacts such as population migration, impacts on health and schooling of children, hopelessness and sense of loss, conflicts in society for water, and malnutrition due to changed food preferences were also reported (Udmale et al., 2014). Agriculture being the major livelihood activity in the rural areas of Western Odisha, is severely affected by droughts (Swain and Swain, 2011). Drought has many profound effects of the farmers living, which can be reflected from his socioeconomic profile. Swain and Swain (2011) studied the nature of vulnerability to agricultural drought in three study blocks of Balangir district in Western Odisha and documented that three most influential socioeconomic factors are: low irrigation development, poor crop insurance coverage and smaller forest area.

From the present study it can be concluded that in drought prone western Odisha (Balangir, Kalahandi, and Nuapada districts) the agricultural farmers stated that drought threatened household food security, erratic rainfall caused drought and subsequent loss of 
crops, distress sale of capital resources due to drought were ranked $1^{\text {st }}, 2^{\text {nd }}$ and $3^{\text {rd }}$ constraints faced by the farmers. Thus, this indicated that the agriculture farmers are severely affected by drought to such an extent that they are not able to maintain the household food requirements.

\section{References}

Campbell, D.J., 1984. Response to drought among farmers and herders in Southern Kajiado District, Kenya. Human Ecology, 12(1), pp.35-64.

Karmee S., 2017.Kosal Discussion and Development Forum. https://kddfonline.com/author/sanjibkar mee/

Son, N.T., Chen, C.F., Chen, C.R., Chang, L.Y. and Minh, V.Q., 2012. Monitoring agricultural drought in the Lower Mekong Basin using MODIS NDVI and land surface temperature data. International Journal of Applied Earth Observation and Geoinformation, 18, pp.417-427.

Swain, M. and Swain, M., 2011. Vulnerability to agricultural drought in Western Orissa: A case study of representative blocks. Agricultural Economics
Research Review, 24, pp.47-56.

Swain, D. P., Goswami, A., Das, B. C., Ganguli, D. and Mahapatra, M. M., 2019. Study on the Constraints of Animal Husbandry Farmers during Drought in Western Parts of Odisha. International Journal of Current Microbiology and Applied Sciences, 8(11), pp.1022-1029. doi: https://doi.org/10.20546/ijcmas.2019.81 1.120

Swain, D. P., 2019. Assessment of animal husbandry as an alternative source of livelihood during drought in western part of Odisha. PhD. Thesis, submitted to the West Bengal University of Animal and Fishery Sciences, Kolkata, West Bengal, India.

Udmale, P., Ichikawa, Y., Manandhar, S., Ishidaira, H. and Kiem, A.S., 2014. Farmers' perception of drought impacts, local adaptation and administrative mitigation measures in Maharashtra State, India. International Journal of Disaster Risk Reduction, 10, pp.250269.

Wilhite, D.A. ed., 2016. Droughts: A global assessment. Routledge.

\section{How to cite this article:}

Devi Prasanna Swain, Arunasis Goswami, Bhabesh Chandra Das, Debasis Ganguli and Bikash Santra 2020. Constraints Faced by Agriculture Farmers during Drought in Drought Prone Western Odisha. Int.J.Curr.Microbiol.App.Sci. 9(10): 2119-2125. doi: https://doi.org/10.20546/ijcmas.2020.910.258 